\title{
The 2006 Mexican Election and Its Aftermath: Editor's Introduction
}

\footnotetext{
C
} ompetition came to Mexico's new democracy with unexpected fury in the nation's 2006 presidential election. Until recently Mexico was the bastion of the Institutional Revolutionary Party (PRI), where opposition parties could rarely hope to gain half as many votes as the PRI. But in the July 2 presidential election, Felipe Calderón of the National Action Party (PAN) edged Ándres Manuel López Obrador of the Democratic Revolutionary Party (PRD) by a mere 233,831 votes, or $0.58 \%$ of the more than 41.5 million cast. The PRI's candidate, Roberto Madrazo, finished a distant third. Calderón took this razor-thin margin after a fiercely competitive campaign marked by lavish media spending and the use of negative attack ads. López Obrador has contested the outcome from the time the polls closed until the present, calling his supporters into the streets on several occasions to put pressure on the electoral authorities to recount the votes; staging an "election by acclamation" in which those present at a rally

by

Joseph L. Klesner, Kenyon College on Mexico's Independence Day "elected" López Obrador by a show of hands; and holding an "inauguration" ceremony on No-

vember 20, the anniversary of the onset of the Mexican Revolution. While López Obrador challenged the preliminary outcome, Calderón had to wait patiently until the Federal Electoral Tribunal (TRIFE) declared him elected on September 5, fully two months after the ballots had been cast.

Getting to the final TRIFE tally proved an arduous chore for everyone involved-electoral authorities, candidates, and the public alike. The preliminary tally by the Federal Electoral Institute (IFE) on Election Night yielded totals that were so close-Calderón led by about 1\%—-that IFE President Luis Carlos Ugalde announced that the autonomous electoral agency could not call the election that night. Neither López Obrador nor Calderón waited, however, for a verdict from the IFE: each came out to announce his victory that evening. The next day, López Obrador challenged the accuracy of the preliminary figures and demanded a full recount of the votes. His case was strengthened when the IFE made changes to the preliminary figures that reduced Calderón's lead to about $0.63 \%$ (Herrera and Zárate 2006). When the vote counts were tallied at the dis- trict level on Wednesday, July 5, Calderón came out ahead by about $0.60 \%$ (see Table 1 ). López Obrador held his first major postelection rally the Saturday after the election. The next day, the Coalition for the Good of All, ${ }^{1}$ of which his PRD was the core, submitted its 800-page brief demanding a full recount to the TRIFE.

From then until the TRIFE's September 5 decision, a dialectic developed, with López Obrador orchestrating mass rallies in Mexico City's central square (shown on the cover of this issue of $P S$ ) to pressure the TRIFE into ordering a recount, only to be countered by Calderón's insistence that the formal mechanisms of vote counting and recounting be followed and his promise to abide by the TRIFE's decision and the final results. In the end, the TRIFE approved a final count that was about 230,000 votes fewer than the IFE's July 6 numbers. The new tally, based on recounting the votes of about $9 \%$ of the polling places, deducted about the same number of votes from both Calderón and López Obrador (see Table 1).

The 2006 presidential elections confounded many pundits with its twists and turns, even before the post-election drama unfolded. A year before the election, Calderón was not expected to be the PAN nominee. However, he took advantage of his status as the consummate PAN insider to soundly defeat President Vicente Fox's favored candidate, Interior Minister Santiago Creel, in the PAN primary. From well before the beginning of the formal election season in January 2006, López Obrador was viewed as the odds-on favorite. He led in public opinion polls from the time news outlets began publishing them until after the first presidential debate took place on April 25, 2006 (CIDAC 2006). But, overconfident of his lead in the polls, López Obrador chose to skip that first debate, and this cost him his lead. He participated and performed well enough in the second debate held on June 6, but he had lost his momentum. Final pre-election polls yielded results so close as to be within the margin of error.

\section{Confextual Factors}

Mexico's was but one of a dozen presidential elections taking place in Latin America between November 2005 and December 2006. In the past two years, Venezuela's Hugo 
Table 1

Results of the 2006 Mexican Presidential Election Initial and Final Vote Tallies

\begin{tabular}{|c|c|c|c|c|c|}
\hline \multirow[b]{2}{*}{ Candidate and Party } & \multicolumn{2}{|c|}{$\begin{array}{c}\text { TRIFE } \\
\text { (September 5, 2006) }\end{array}$} & \multicolumn{2}{|c|}{$\begin{array}{c}\text { IFE } \\
\text { (July 6, 2006) }\end{array}$} & \multirow{2}{*}{$\begin{array}{l}\text { Vote Count } \\
\text { Difference } \\
\end{array}$} \\
\hline & Votes & Percent & Votes & Percent & \\
\hline Felipe Calderón (PAN) & $14,916,927$ & 36.69 & $15,000,284$ & 36.69 & $-83,357$ \\
\hline Andrés Manuel López Obrador (PRD, PT, C) & $14,683,096$ & 36.11 & $14,756,350$ & 36.09 & $-73,254$ \\
\hline Roberto Madrazo (PRI, PVEM) & $9,237,000$ & 22.72 & $9,301,441$ & 22.75 & $-64,441$ \\
\hline Patricia Mercado Castro (PASC) & $1,124,280$ & 2.77 & $1,128,850$ & 2.76 & $-4,570$ \\
\hline Roberto Campa (PANAL) & 397,550 & 0.98 & 401,804 & 0.98 & $-4,254$ \\
\hline Unregistered & 298,204 & 0.73 & 297,989 & 0.73 & -215 \\
\hline Total Valid Votes & $40,657,057$ & 100.00 & $40,886,718$ & 100.00 & $-229,661$ \\
\hline Nullified Votes & 900,373 & 2.17 & 904,604 & 2.16 & $-4,231$ \\
\hline Total Votes & $41,557,430$ & 100.00 & $41,791,322$ & 100.00 & $-233,892$ \\
\hline
\end{tabular}

Chávez has become a media sensation, successfully drawing attention to himself and his anti-George W. Bush, anti-U.S. foreign policy message. With the victory of Chávez's ally Evo Morales in Bolivia, media commentators came to characterize this unusually concentrated round of president elections as a hemisphere-wide choice between Left and Right. ${ }^{2}$ Because López Obrador's campaign offered a populist message, he was typically placed in the category of candidates whose victory would reflect a "tilt to the Left." In this debate about Latin America's turn to the Left, prominent Mexican political scientist and former Minister of Foreign Affairs Jorge Castañeda (2006) even sought to distinguish between responsible, socialdemocratic reformers like Brazil's Luiz Inacio "Lula" da Silva and Chile's Ricardo Lagos and Michelle Brachelet, on one hand, and irresponsible populists like Chávez, on the other, implying that López Obrador came closer to the latter group than the former. The Calderón campaign picked up on this theme to paint López Obrador as a threat to Mexican stability.

As Alejandro Moreno shows in his contribution to this symposium, the dimension of Mexicans' lives that might have been threatened by an irresponsible populist was economic stability. Fox did not make good on his campaign pledge to produce annual economic growth rates of $7 \%$. Indeed, in the first half of Fox's presidency the impact of the U.S. economic slowdown, especially after the attacks of September 11, 2001, impaired the Mexican economy in exactly the way one would expect given the increasingly tight economic relationship between the two countries that has emerged as a result of the North American Free Trade Agreement (NAFTA). But Fox's government has produced macroeconomic stability and increased economic growth since 2003, helped considerably of late by rising oil prices, as Moreno notes. In this context, we might expect Mexicans to act as retrospective economic voters, and Moreno indicates that they did so in July. Because Mexico had enjoyed economic stability, even growth, in the last two-and-a-half years, many Mexicans worried that the change they might produce by voting for López Obrador could threaten economic continuity. Those who had positive evaluations of the economy hence voted for continuity-for Calderón.

But why would those worried by López Obrador's potential threat to economic stability choose Calderón, and not the PRI's
Madrazo? In 2003, it would seem, the PRI received the votes of the economically discontent. ${ }^{3}$ In her contribution to this symposium, Joy Langston details the challenges facing the PRI now that it no longer controls the central government as well as the missteps taken by Madrazo as he seized control of the party presidency in the aftermath of the PRI's historic defeat in 2000. The performance of the PRI's congressional candidates indicates that the party's presidential standard-bearer was not predestined to finish last among the top three candidates. However, Madrazo's public image when he began the campaign was already tainted by past allegations of electoral fraud. Additionally, he had alienated important powerbrokers among his own party's leaders, especially the PRI's second most powerful figure, Elba Esther Gordillo, the head of the national teachers' union. Madrazo ran a lackluster campaign at the head of a party of which significant sectors failed to support him; he finished well behind Calderón and López Obrador. Fortunately for the PRI, the party gained enough congressional seats that it should figure prominently in any effort by Calderón to forge a congressional coalition, as Langston describes.

\section{A Divided Society?}

A central preoccupation of post-electoral analysts has been the apparent deep divisions in Mexican society manifested by the strident post-election rallies led by López Obrador. This symposium's contributors take this concern not as a given to be explained, but as an empirical observation that first must be verified. Let this symposium serve to stamp out this misconception-our evidence does not support the conclusion that Mexican society is deeply divided along the lines usually associated with profound political cleavages. Nor has the long decline of the PRI resulted in a realignment of the parties' social bases (Klesner 2005).

Because Mexico's transition to democracy has come by an electoral path, many political scientists studying Mexican politics-both Mexicans and foreigners-have opted to concentrate on public opinion and electoral dynamics, borrowing methodologies freely from the study of politics in the United States. This symposium's contributors have been heavily involved in generating new sources of data to analyze Mexican political 
processes and mass political behavior. We bring to this symposium some early analysis of the 2006 election based on these new data sources, including perhaps the most comprehensive of those datasets, the Mexico 2006 Panel Study, a three-wave panel survey that focused on issue formation during the 2006 campaign. ${ }^{4}$

My contribution to this symposium explores the parties' social and political bases as manifested in the 2006 election. My evidence from the Mexico 2006 Panel Study suggests little in the way of profound social cleavages, at least as reflected in the mass electorate, for López Obrador's voters proved a fairly heterogeneous group. A geographic division, north-south (blue and yellow Mexico), does emerge, but the presence of the PRI as a competitor to the PAN in the north and the PRD in the south serves to soften the regional cleavage.

In their article, Kathleen Bruhn and Kenneth Greene take a careful look at how PAN and PRD voters self-identify on important issues, both economic and social/moral. Despite the rhetoric of the campaign, PAN and PRD voters prove to be fairly close to each other on a wide-range of important issuesprivatization of the electricity sector, the role of government in promoting individual welfare, and abortion. Mexican society, this evidence suggests, is not profoundly divided.

\section{A Divided Elite?}

However, the Mexican elite is another matter. In the same article, using their Mexico 2006 Candidate and Party Leader Survey, Bruhn and Greene show that congressional candidates of the PRD and the PAN are far more polarized on these same issue dimensions than those who voted for them. Further, PAN elites place PRD leaders farther to the extreme on policy issues than PRD elites claim to be, and vice versa. In short, those most active in the former opposition parties are pushing the policy debate farther to the extremes

than the electorate would itself choose, and these same elites are strongly inclined to assume the worst of their adversaries.

In the post-election period, we have seen this elite polarization become as severe as any time since the 1988 election, in which Cuauhtémoc Cárdenas, candidate for the political front that later became the PRD, lost a fraud-ridden election to the PRI's Carlos Salinas. In those days, of course, the PRI had a stronger grasp on power and on the state apparatus than the PAN can claim today, and it yielded little in the immediate aftermath of Salinas's election. But as Todd Eisenstadt's contribution to this symposium reminds us, in the decade after that contested 1988 electoral outcome the PAN and the PRI engaged in numerous post-electoral renegotiations of results, generally to the PAN's advantage. The PRD, in contrast, seldom benefited by pressing for post-electoral negotiations, although López Obrador did: he rode to the top of the PRD on the basis of those successes. To truly understand the character of the 2006 post-election conflict, we must appreciate the historical underpinning for López Obrador's actions: based on his past successes in post-electoral negotiations, López Obrador expected that he could either extract concessions from the PAN or pres- sure the electoral authorities to engage in recounts, even if the formal rules did not allow them to do so. This time he failed to gain those concessions as the PAN and recently bolstered electoral institutions stood firm for legality rather than for political compromise, but his attempt put the entire political system under considerable stress.

The unusual character of the Mexican transition-protracted democratization via the electoral path-has led many political scientists to focus on mass electoral behavior and public opinion, as I mentioned above. In the course of focusing so intently on those critical dimensions of the Mexican transition, we have paid less attention to concepts covered more thoroughly by analysts of other transitions to democracy. Most importantly, we have given relatively little attention to elite-level politics, as Chappell Lawson argues in his article in this symposium. Lawson steps back to set the election and post-electoral events into a broader frame, that of Mexico's lengthy process of liberalization and democratization. Because of the peculiarities of political recruitment into the PAN and the PRD, elites in neither party accurately reflect the views of their respective electorates, and they find their views on many issue dimensions in stronger opposition to those of the elites in the opposing party than to the relatively moderate views of the public, as Bruhn and Greene make clear. Elite-level politics has become highly conflictual, but Lawson argues that institutional engineering may not offer the way out of the current impasse. To fully appreciate how Mexican democracy might be deepened, we must pay close attention to elite-level politics.

\section{To the Future}

Many Mexicans, ordinary citizens and the politically active alike, saw Fox's victory in the 2000 presidential election as the final step in a protracted transition from single-party dominance to competitive democracy. The PRI had remained in power for over seven decades by highlighting its continuity with the Revolution, stressing its revolutionary nationalist credentials, carefully spreading the patronage that it enjoyed as the governing party in an economy dominated by the state, and, when victory demanded it, engaging in selective electoral fraud. Over the decades, Mexicans came to doubt the integrity of their electoral institutions. Building a new set of electoral institutions that could assure all sides that electoral processes were transparent, clean, and fair was critical to Mexico's protracted transition from singleparty rule. Outside observers agreed that from 1994 onward, that standard had been met. They did so again in 2006. However, López Obrador's challenge to the electoral outcome has put the integrity of the electoral institutions into question for a minority of the population, and his resort to public protest-direct democracy, in his view; an attempt to circumvent legitimate democratic institutions, in the perspective of his opponents-has set Mexico back on its quest to consolidate and deepen democracy. Felipe Calderón faces the difficult task of healing the divisions generated by his election while simultaneously addressing the significant policy challenges posed to his nation.

\section{Notes}

1. Coalición por el Bien de Todos can be literally translated as the Coalition for the Good of All, which has generally been how English-language journalists have rendered it. A translation that better captures the spirit of the alliance would be Coalition for the General Welfare. However, we use the common usage here so as to avoid confusion.

2. Latin American presidents sit for four-, five-, or six-year terms, with many nations (including Mexico) forbidding reelection. Therefore, the November 2005 to December 2006 period reflects the coincidence of presidential elections rather than a normal four-year cycle when these elections occur nearly simultaneously. Of the large Latin American countries, only 
Argentina did not hold a presidential election during this 13-month time frame. See Klesner 2006 for a summary.

3. Preliminary analysis of the 2003 Comparative Study of Electoral Systems survey for Mexico suggests that the PRI captured economically discontented voters.

4. The Mexico 2006 Panel Study surveyed 2,400 voters in October 2005: 1,600 in a national sample, along with an oversample of 500 from the Federal District (Mexico City) and a rural oversample of 300 in the states of Chiapas, Jalisco, and Oaxaca. The second wave of the panel was administered in May 2006, with the final wave after the election in July 2006. To help mitigate the loss of representativeness due to respondent attrition, addi- tional cross-sectional surveys were administered simultaneously in the May and July waves ( $\mathrm{N}=305$ and 400 , respectively).

Senior Project Personnel in the Mexico 2006 Panel Study include (in alphabetical order): Andy Baker, Kathleen Bruhn, Roderic Camp, Wayne Cornelius, Jorge Domínguez, Kenneth Greene, Joseph Klesner, Chappell Lawson (Principal Investigator), Beatriz Magaloni, James McCann, Alejandro Moreno, Alejandro Poiré, and David Shirk. Funding for the study was provided by the National Science Foundation (SES-0517971) and Reforma newspaper; fieldwork was conducted by Reforma newspaper's Polling and Research Team, under the direction of Alejandro Moreno. See http://web.mit.edu/polisci/research/mexico06/index.htm.

\section{References}

Bruhn, Kathleen, and Kenneth F. Greene. 2007. "Elite Polarization Meets Mass Moderation in Mexico's 2006 Elections.” PS: Political Science and Politics 40 (January): 33-38.

Castañeda, Jorge G. 2006. "Latin America's Left Turn." Foreign Affairs 85 (May/June): 28-43.

CIDAC. 2006. "Poll of polls junio 2006." Mexico City: Centro de Investigación para el Desarrollo, A.C. Available at www.cidac.org. Last accessed on 20 November 2006.

Eisenstadt, Todd A. 2007. "The Origins and Rationality of the 'Legal versus Legitimate' Dichotomy Invoked in Mexico's 2006 Post-Electoral Conflict." PS: Political Science and Politics 40 (January): 39-43.

Herrera, Jorge, and Arturo Zárate. 2006. "Se reduce la ventaja de Calderón sobre AMLO.” El Universal, July 5, 2.

Klesner, Joseph L. 2005. "Electoral Competition and the New Party System in Mexico." Latin American Politics and Society 47 (summer): 103-42.

SYMPOSIUM AUTHORS' BIOS

Kathleen Bruhn is associate professor of political science at the University of California, Santa Barbara. She is the author of two books on Mexican politics, most recently, Mexico: The Struggle for Democratic Development (with Daniel C. Levy). She is currently completing a manuscript on urban protest in Mexico and Brazil.

Todd A. Eisenstadt teaches political science at American University's School of Public Affairs, where he is also principal researcher of the United States Agency for International Development (USAID) Higher Education and Development Program grant: "Uniting Law and Society in Oaxaca, Mexico: A Research and Teaching Program." He is the author of Courting Democracy in Mexico: Party Strategies and Electoral Institutions (Cambridge University Press, 2004), and several articles on Mexico's democratization.

Kenneth F. Greene is assistant professor of government at the University of Texas at Austin. He is Co-Principal Investigator on the Mexico 2006 Panel Study and author of Defeating Dominance: Party Politics and Mexico's Democratization in Comparative Perspective (Cambridge University Press, forthcoming).

Joseph L. Klesner is professor and chair in the department of political science at Kenyon College. He has recently published articles on Mexican politics and on political participa-

tion in Latin America in the Latin America Research Review, Nationalism and Ethnic Politics, and Latin American Politics and Society.

Joy Langston is a research professor at the Center for Teaching and Research in Economics (CIDE) in Mexico City. Her research centers on political parties in Latin America and Mexico, and her work has been published in Party Politics and Comparative Political Studies.

Chappell Lawson is associate professor of political science at the Massachusetts Institute of Technology and non-resident fellow at the Pacific Council on International Policy. He is the co-editor (with Jorge Domínguez) of Mexico's Pivotal Democratic Election and author of Building the Fourth Estate: Democratization and the Rise of a Free Press in Mexico.

Alejandro Moreno is professor of political science at the Instituto Tecnológico Autónomo de México (ITAM) and head of the department of surveys at Reforma newspaper, both in Mexico City. He has published over 30 articles in journals and edited volumes and is the author of Political Cleavages (1999), El Votante Mexicano (2003), and Nuestros Valores (2005), as well as co-author of Human Values and Beliefs (1998), with Ronald Inglehart and Miguel Basáñez. 